THE AMERICAN JOURNAL OF SOCIAL SCIENCE AND EDUCATION INNOVATIONS

[Volume-II Issue-VI][Pages = XII-XVIII] [2020]

Website: www.usajournalshub.com

ISSN (e): 2689-100X

\title{
TOPICAL ISSUES OF THE ESTABLISHMENT OF THE LEGAL STATUS OF ADVOCACY STRUCTURES
}

\author{
Davlyatov Valisher \\ Head Of Department Of The Legislation And Parliamentary Research Institute \\ Under The Oliy Majlis Of The Republic Of Uzbekistan, Independent Researcher At The \\ Tashkent State University Of Law.
}

Article Doi - https://doi.org/10.37547/tajssei/Volume02Issue06-03

Abstract: The article discusses topical issues of the legal status of advocacy structures, the current state of advocacy in the Republic of Uzbekistan, areas for improvement of the advocacy structures, the existence of commercial, non-commercial and mixed forms of advocacy on the example of foreign countries.

Keywords: the institute of advocacy, advocacy structures, structures of law firms, advocacy bureau, advocacy firm, board of attorneys, attorney's license, legal entity, noncommercial legal entity.

\section{Introduction}

One of the most important features of civil society and legal state is being in a relationship based on the deep respect for the institute of advocacy and its activities. The special attention given to the advocacy in the process of judicial and legal reforms carried out in the Republic of Uzbekistan shows that similar relations are being formed in terms of the protection of human rights in the country.

The fundamental reforms in all areas in Uzbekistan over the past three years require the parallel development of the institution of advocacy and the improvement of its legal framework. The advocacy system as an integral part of civil society is directly interested in the reforms carried out in Uzbekistan, particularly, in positive changes in the judicial-legal system. [1; p. 239].

The Decree of the President of the Republic of Uzbekistan "On measures to radically increase the effectiveness of the institution of advocacy and expand the independence of attorneys" dated May 31, 2018 No. UP-5441 ushers in a new era in improving the institution of advocacy. 


\section{THE AMERICAN JOURNAL OF SOCIAL SCIENCE AND EDUCATION INNOVATIONS \\ [Volume-II Issue-VI][Pages = XII-XVIII] [2020] \\ Website: www.usajournalshub.com \\ ISSN (e): 2689-100X}

Currently, there are about 100 normative-legal acts regulating the institution of advocacy. Most of them are by-laws. At the ceremony dedicated to the 26th anniversary of the adoption of the Constitution of the Republic of Uzbekistan and in the State Program for 2019, President Sh. Mirziyoyev emphasised the need for bringing lawmaking activities to a qualitatively new level and adopting laws with direct action [2].

Organizational-legal units of advocacy structures play an important role in advocacy activities. According to the Law of the Republic of Uzbekistan "On advocacy", a person who has received the license in the established order shall be entitled to carry out advocacy activities individually by opening an advocacy bureau, or by forming with other attorneys (partners) an advocacy firm, or board of attorneys on the basis of membership, or join in one of these existing advocacy structures, or to engage in advocacy activities working in a legal consultation office. Advocacy as a public organization has specific features. As $\mathrm{K}$. Yanevsky wrote, "... public organizations are organizations that are formed by a certain social group and represent the interests of citizens belonging to this social group. For example, political parties, trade union and other organizations serve the interests of party members, trade unions, and workers respectively. The advocacy serves to protect the rights of all citizens in society as a whole, and not just members of this public organization "[ 3 ; $p$. 15].

There emerges another important issue. Article 11 of the Law of the Republic of Uzbekistan "On guarantees of advocacy activity and the social protection of attorneys" indicates that the advocacy is a non-commercial legal entity.

The civil legislation regulates the majority of social relations relating to the legal status of advocacy structures such as the establishment of advocacy structures, property issues, and other relations. Thus, it remains an unsolved issue in terms of which type of legal entities the advocacy structures should be referred to.

Profit-making is not considered as the main goal of advocacy structures. However, having investigated the activity of advocacy structures, it could be noted that the classification of advocacy structures in terms of their goal of establishment does not reveal their legal status. Therefore, it would be truly ascertained that profit-making is not the goal of the advocacy structures but the directions of their activity.

The non-commercial nature of advocacy is directly enshrined in the legislation of Uzbekistan. Thus, in accordance with article 11 of the Law of the Republic of Uzbekistan "On guarantees of advocacy and social protection of attorneys" dated December 25, 1998, it is stated that 'an advocacy structure' is a non-profit organization. The determination of this status, according to the opinion of a lawyer and a scientist L.B.Hwang, has brought about three different approaches related to a legal status of advocacy structures: 


\section{THE AMERICAN JOURNAL OF SOCIAL SCIENCE AND EDUCATION INNOVATIONS \\ [Volume-II Issue-VI][Pages = XII-XVIII] [2020] \\ Website: www.usajournalshub.com \\ ISSN (e): 2689-100X}

- an advocacy structure is a "professionally oriented legal entity, considered as a subject of law, but not a business entity";

- organizational forms of the activities of advocacy are legal entities that are subject to many general provisions of Chapter 4 "Legal Entities" of the Civil Code of the Republic of Uzbekistan. At the same time, the rules of paragraph 2 of this Chapter, which regulate the status of commercial legal entities, do not apply to the activities of organizational forms of the advocacy activities;

- organizational forms of the advocacy activities are non-profit legal entities, but not within the meaning of the Law of the Republic of Uzbekistan "On non-governmental nonprofit organizations" of April 14, 1999, i.e. these are subjects of law that differ from the legal status of legal entities that are classified as non-profit organizations such as "public association", "public fund", "consumer cooperatives", etc.

It is worth noting that according to Article 4 (1) of the Law of the Republic of Uzbekistan "On Advocacy", an advocacy bureau is an advocacy structure, which is a noncommercial legal entity, established by an attorney for the individual implementation of advocacy activities.

Having analyzed the past, we could notice that the Law "On Advocacy" of the Republic of Uzbekistan determined for the first time the possibility of the establishment of an advocacy firm and a bureau of advocacy along with a board of attorneys operating in practice as an organizational legal form of advocacy activity.

Paying attention to the historical development of advocacy bureaus and the tendency of their progress, it should be noticed that this form of advocacy structure has been widely disseminated in recent years. In particular, the number of registered advocacy bureaus in Uzbekistan was 80 as for July 1, 1997; as for January 1, 2005 was 289 and as for January 1,2007 , their number reached 438 , consequently, by January 1,2019 , there were 1154 advocacy bureaus operating in the republic.

The analysis of the experience of foreign countries shows that in order to engage in individual advocacy activities, there is a requirement that a person should be engaged in the advocacy firm or board of attorneys for a certain period (for example, five years in the Russian Federation).

Therefore, it is of paramount importance to establish a special rule in the legislation for the organization and the functioning of the advocacy bureaus. In particular, it is desirable to allow individuals to operate individually by means of establishment of bureaus of advocacy who have served at least three years as an attorney in the advocacy firm or board of attorneys, which are considered as organizational forms of advocacy structures.

The analysis of the experience of foreign countries shows that the models associated with the legal status of advocacy structures are mainly of the following three approaches. 


\section{THE AMERICAN JOURNAL OF SOCIAL SCIENCE AND EDUCATION INNOVATIONS \\ [Volume-II Issue-VI][Pages = XII-XVIII] [2020] \\ Website: www.usajournalshub.com \\ ISSN (e): 2689-100X}

According to the first approach, advocacy structures are commercial organizations, which means that their main goal is to gain a profit. This practice is common in countries such as the United States, Canada, Great Britain, and etc.

For example, in the United States there are law firms with an individual form (sole attorney) and collective form (law corporations). In the United States, the tendency of lawyers to move from individual to collective form is reflected in two directions: first, the establishment of law firms on the basis of hiring lawyers (employment contracts), and second, the practice of individual lawyers (solo lawyers) when two or three people began to establish law firms under certain conditions [4].

The legal regulation of organizational and legal forms of advocacy is not clearly defined either at the federal level or at the state level. In the United States, bar associations are enacted in the Uniform Partnership Act of 1914, in the revised Uniform Partnership Act of 1994, and in the Limited Liability Companies Act of 1995 and also governed by state corporate codes (e.g., California Corporate Code).[5,64]

Lawyers in the United Kingdom are divided into two large groups - attorneys (barristers) and solicitors.

In the UK solicitors (singular a solicitor) is a category of lawyers specializing in independent business in the magistrates' courts of counties and city-counties and in preparing materials for barristers - lawyers of a higher rank. Solicitors also perform the functions of legal advisers in institutions, enterprises, organizations, joint-stock companies.

To become a solicitor, one must work for another 5 years with another solicitor as an assistant or in a responsible position (for a graduate with a university education this period is 3 years). Interestingly, admission to the solicitors is not made by the Law Society, but by the chairman of the Court of Appeal of the corresponding county.

The essence of the work of the solicitor is to provide a wide range of legal services to the public: from real estate transactions to drafting contracts to business entities and resolving inheritance issues. Solicitors can also deal with lawsuits about causing harm to health (torts), act as legal advisers (mainly civil cases), and conduct business on behalf of their clients in criminal trials.

Lawyers of the so-called "higher caste" are barristers. They offer specialized services of lawyers in cases related to litigation, as a rule, they have a narrow specialization in certain areas of law.

The word "barrister" comes from the English barrister, from bar - the barrier that separates the judge from the defendant and is the highest lawyer in Britain. Barristers conduct business and make speeches before the court, unlike solicitors and attorneys, authorized only to submit papers and documents. 


\section{THE AMERICAN JOURNAL OF SOCIAL SCIENCE AND EDUCATION INNOVATIONS \\ [Volume-II Issue-VI][Pages = XII-XVIII] [2020] \\ Website: www.usajournalshub.com \\ ISSN (e): 2689-100X}

In England and Wales, there are about 8 thousand practicing barristers; the professional council of barristers is the General Council of the Bar. Barristers act as advocates for most major cases in English courts.

Barristers receive highly competitive training in litigation and judicial defense at special courses on their specialty. The main emphasis in training programs is put on advocacy skills, the judicial procedures and the rules for collecting and presenting evidence, as well as on the ability to quickly get acquainted with the memorandum on the case.

To obtain the title of a barrister, one must have a higher legal education (master's degree in law). It is noteworthy that only a few universities give such an education. They should also take three years of training in one of the law firms and pass the exam of a lawyer in legal disciplines. In practice, the transition to the "caste" of barristers is carried out from the ranks of attorneys and solicitors.

Under the second approach, the legal status of advocacy structures is considered as that of non-commercial organizations. The criteria for this approach corresponds to the legal status of advocacy structures of CIS member states.

In particular, according to Article 20 of the Law of the Russian Federation "On advocacy and advocacy activities", the advocacy structures are cabinet of an attorney, board of attorneys, advocacy bureau and legal consultation office. A lawyer with at least three years of legal experience as an attorney may practice law on an individual basis establishing a cabinet of an attorney. The cabinet of an attorney is not a legal entity. The status of a board of attorneys, advocacy bureau and legal consultation office is almost the same as that of a board of attorneys, advocacy bureau and legal consultation office operating in the Republic of Uzbekistan, respectively.

In the Ukraine, according to Article 4 of the new Law "On Advocacy and Advocacy activities" adopted on July 5, 2012, a lawyer may practice law individually or in a form advocacy bureau or in a board of attorneys [6].

The Law of the Republic of Belarus "On advocacy" was adopted on December 30, 2011. According to Article 29 of the Law, a lawyer may practice law in a legal consultation office or in a law firm, or also individually. A lawyer who decides to practice law individually or as a founder (managing partner) in a advocacy bureau must have at least three years of advocacy experience[7].

According to the third approach, the legal status of advocacy structures is mixed, that is, they are in practice considered as both commercial and non-commercial organizations. A classic example of this approach is that of the French Republic.

In France, several collective forms are contributing to the organization of the attorneys' activity and participation in advocacy structures, in particular, "United civil partnerships based on the accumulation of funds", "Advocacy offices in the group" and 


\section{THE AMERICAN JOURNAL OF SOCIAL SCIENCE AND EDUCATION INNOVATIONS \\ [Volume-II Issue-VI][Pages = XII-XVIII] [2020] \\ Website: www.usajournalshub.com \\ ISSN (e): 2689-100X}

"Unions based on economic incentives"; as well as there are partnerships of a commercial type such as "Liberal professional partnerships with limited liability", "Liberal professional partnerships in the form of joint-stock companies" and "Liberal professional partnerships in the form of special joint-stock companies".

In the course of our research, a sociological survey was conducted in June and July 2019 among 1550 attorneys on the topic called "What should be the legal nature of the advocacy in the future in case of necessary reforms?" $43.4 \%$ of respondents (673 attorneys) expressed the opinion that they should be in a form of a non-commercial legal entity, while $4.7 \%$ of respondents (73 attorneys) voted for a commercial form of advocacy structures and the remaining part of participants, $46.5 \%$ (720 attorneys), considered that they should be in a mixed form.

Taking into consideration the aforementioned, to resolve thoroughly the issues related to the legal status of advocacy structures and sufficiently advance their legal nature, it is proposed to introduce the following edition of the third part of Article 40 of the Civil Code of the Republic of Uzbekistan:

"A legal entity that is not a commercial organization can be established in the forms of a public association, social fund and institution, established and financially funded by the owner, advocacy structures, as well as in other forms provided for by the legislation."

It is of paramount significance to the state that the current edition of Article 40 provides for an expanded, i.e. an open list of legal entities. Additionally, through defining the advocacy structures as a separate form of non-commercial legal entities we would clarify their role in taxation and other relations.

Furthermore, it is worthwhile to introduce the provisions constituting the organizational and legal forms of advocacy structures into the relevant articles of the Civil Code the Republic of Uzbekistan.

Consistent implementation of these proposals would further enhance the role and importance of the advocacy institute in developing the legal status of the advocacy structures in Uzbekistan, increasing the attractiveness of the profession of an attorney, and especially, in ensuring the protection of rights, freedoms and legitimate interests of the citizens.

\section{References}

1. Salomov B. "The role of the advocacy in the protection of human rights" // Materials of a scientific-practical conference on the problems of judicial and extrajudicial protection of human rights. T.: TSUL, 2005. 
THE AMERICAN JOURNAL OF SOCIAL SCIENCE AND EDUCATION INNOVATIONS

[Volume-II Issue-VI][Pages = XII-XVIII] [2020]

Website: www.usajournalshub.com ISSN (e): 2689-100X

2. S. Mirziyoyev "An educated generation is the key to a great future, entrepreneurs prosperous life, and friendly cooperation is the key to progress." [Text] // Public speech, December 8, 2018, Narodnoe slovo No. 253 (7211).

3.Yanevsky K. Attorney and advocacy in Russia. - M .: Yurid. lit., 1992.

4.Pulyanov V.Z. US Lawyers: Organization and Forms of Professional Activity // All-Russian Research Institute of Soviet Legislation. Problems of improving Soviet legislation. Proceedings. Vol. 1.

5.Shchukovskaya O. M. Forms of activities for the provision of legal services // Lawyer (magazine). 2001. No. 10.

6.https://zakon.rada.gov.ua/laws/show/5076-17

7.http://gka.grodno.by/norm-base/37-zakon_ob_advokature.html 